\title{
Study of Sukhana Dam, Concerning Water Parameters Dist, Aurangabad, (M.S.) India
}

\author{
Ashok Sayasrao Munde ${ }^{1}$, Purushottam R More ${ }^{2}$, Sunil Eknath Shinde ${ }^{3^{*}}$ \\ ${ }^{1}$ Assistant Professor, Department of Zoology, Sambhajirao Kendre Mahavidyalaya, Jalkot (M.S.) India \\ ${ }^{2}$ Assistant Professor, Department of Zoology, kai. Rasika Mahavidyalaya, Deoni (M.S.) India \\ ${ }^{3}$ Assistant Professor, Department of Zoology, M. J. P. V. Arts, Commerce, and Shri. V. K. K. Science College, Dhadgaon
}

(M.S.) India

*Address for Correspondence: Dr. Sunil Eknath Shinde, Assistant Professor, Department of Zoology, M. J. P. V. Arts, Commerce, and Shri. V. K. K. Science College, Dhadgaon Dist. Nandurbar (M.S.), India

E-mail: sunilshinde1684@gmail.com

Received: 22 Apr 2021/ Revised: 24 June 2021/ Accepted: 09 Aug 2021

\begin{abstract}
Background: An examination of the water from various aspects becomes essential. However, the percentage of water resources used for non-irrigation purposes is currently low, expected to increase significantly in the future with growing industrialization and energy production. Conservation and efficient use of available water resources requires the utmost attention. Therefore, it is necessary to think carefully about future decisions on water management.

Methods: Water samples were taken for physicochemical analysis at the Sukhana Dam in Aurangabad, Maharashtra, India, early in the morning between 8:00 and 11:00 AM in the first week of each month.

Results: The present study deals with assessing the water quality, seasonal variations, and Correlation between parameters of Sukhana Dam at Aurangabad, Maharashtra, India. The physicochemical characteristics were studied and analyzed from July 2008June 2009. The results revealed that the condition of these dams in various seasons concerning the parameters. The physicochemical parameters; with the help of this understanding, the water quality of the dam and the correlation coefficient shows a highly significant positive and negative relationship $(p<0.01)$ and also a significant positive and negative relationship $(p<0.05)$ these parameters are correlated with the different seasons. Correlation coefficients are used to measure the strength of the association between parameters.

Conclusion: During the present investigation, the observed all parameters values within the permitted limit specified by the ISI, which indicates that the dam's water is suitable for drinking and domestic purposes.
\end{abstract}

Key-words: Physico-chemical parameters, Seasonal variations, Sukhana Dam, Water quality, Water parameter

\section{INTRODUCTION}

In many countries, water scarcity is becoming a growing obstacle not only for family care but also for economic activity in general. The upstream water makes the downstream river so short that the industry is forced to close seasonally. In the Indonesian regional capital Surabaya, this has become routine. As industry, irrigation and people expand, so does the economic and environmental cost of investing in additional water

How to cite this article

Munde AS, More PR, Shinde SE. Study of Sukhana Dam, Concerning Water Parameters Dist, Aurangabad, (M.S.) India. SSR Inst. Int. J. Life Sci., 2021; 7(5): 2853-2859.

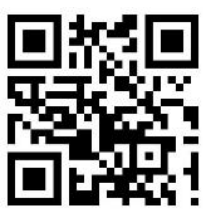

Access this article online https://iijls.com/ resources. Access to drinking water is still an urgent human need in many countries. Aquatic biodiversity is threatened primarily by human abuse and mismanagement of both living resources and the ecosystems that support them. Most of the reservoirs are getting polluted due to domestic waste, sewage, industrial and agricultural effluents ${ }^{[1]}$. Part of the problem is pollution. The diseases that are largely defeated by installing suitable water and sewage systems cause enormous human suffering. The problem is exacerbated in some places by increasing water shortages, making it difficult to meet growing demand. Human waste poses a significant health risk to the many people who are forced to drink and wash in the untreated water of rivers and ponds. UNEP's Global Environmental Monitoring System (GEMS) data show the 
enormous problem of such contamination with poor and deteriorated surface water quality in many countries ${ }^{[2]}$. In countries that can afford to treat all water supplies, human wastewater pollution is lower, and even in some high-income countries, water quality has continued to deteriorate. The decomposition of pollutants reduces the amount of dissolved $\mathrm{O}_{2}$ in the water and reduces the river's ability to support aquatic life. Loss of oxygen does not directly jeopardize health but can have an economic impact on fishing. Human wastewater and agroindustrial wastewater are the leading causes of this problem ${ }^{[3]}$.

Another factor is the release of nutrients from agricultural areas with the intensive use of fertilizers. Although insufficient amounts of dissolved oxygen tended to affect shorter lengths or rivers than faecal contamination, a sample from GEMS monitoring agencies in the mid-1980s found that $12 \%$ had sufficient dissolved oxygen content ${ }^{[4]}$, low to accommodate fish stocks. Endangering the problem was worse when rivers flowed through large cities or industrial centres. The requirement of water in all lives, from micro-organisms to man, is a serious problem today because all water resources have reached a point of crisis due to unplanned urbanization and industrialization. Water quality assessment generally involves analysis of physicochemical and biological parameters and reflects on the abiotic and biotic status of the ecosystem ${ }^{[5]}$. In China, only five of the 15 river sections near significant cities have fed the fish. High-income countries have improved slightly in the past decade. Middle-income countries showed no change in the average, and lowincome countries continued to deteriorate ${ }^{[6]}$.

Different climatic conditions found in India: Summer from February to May, Monsoon from June to September and winter from October to January. In tropical countries, there may be a direct link between the duration of the sun and the temperature ${ }^{[7]}$.

The present study was conducted to assess the water quality of the Sukhana Dam at Aurangabad, Maharashtra, India, which is essential for human use in this environment. Residents use the water for drinking, domestic, agricultural, and recreational purposes ${ }^{[6]}$.

\section{MATERIALS AND METHODS}

Study Area- The Sukhana dam is situated near the village Garkheda in Aurangabad tahsil. It is built over the Sukhana River which passed through the Chikalthana suburb, known for Breweries and Pharmaceuticals' industrial hub. It is $22 \mathrm{~km}$ away from the East side of Aurangabad city between $14^{\circ} .48^{\prime} 36^{\prime \prime}$ North latitude, $75^{\circ} .30^{\prime \prime}$ East longitude. The dam was constructed in the year 1968 as a medium irrigation dam. Soil has been used as bunding materials, the bund height is 16.92 meters and the catchments area is about 21.34 Sq.km. The Top width of the bund is about 3.00 meters. The dam is surrounded by greyish laetrile and black soil.

Samples collection- Water samples were taken for physicochemical analysis at the Sukhana Dam in Aurangabad, Maharashtra, India, early in the morning between 8:00 AM and 11:00 AM in the first week of each month from July 2008-June 2009. Samples were collected in an acid-washed five-litre plastic container at a depth of 5 to $10 \mathrm{~cm}$ below the water's surface. Separate samples were collected to dissolve the oxygen in $250 \mathrm{ml}$ bottles, and the dissolved oxygen was fixed in the field by adding an alkaline iodide-azide solution immediately after collection. The samples were analyzed directly and returned to the laboratory.

The status of the Dam water quality has been determined seasonally, that is, summer, monsoon, and winter. Physicochemical properties such as Rainfall, Atmospheric and Water temperature, $\mathrm{pH}$, dissolved oxygen (DO), Free Carbon Dioxide $\left(\mathrm{CO}_{2}\right)$, and Calcium have been seasonally determined in monthly variation in Site A. and B. using standard methods ${ }^{[8,9]}$.

Table 1: Determination of Physicochemical parameters

\begin{tabular}{|c|c|c|}
\hline S. No. & Parameters & Tests \\
\hline 1 & Rainfall & $\begin{array}{l}\text { Data provided by Govt. of } \\
\text { Maharashtra office Tq. } \\
\text { Aurangabad, } \\
\text { Aurangabad. }\end{array}$ \\
\hline 2 & $\begin{array}{l}\text { Atmospheric } \\
\text { Temperature }\end{array}$ & $\begin{array}{l}\text { Recorded by using } \\
\text { Mercury thermometer }\end{array}$ \\
\hline 3 & $\begin{array}{c}\text { Water } \\
\text { Temperature }\end{array}$ & $\begin{array}{l}\text { Recorded by using } \\
\text { Mercury thermometer } \\
\text { dipping in water up to } 10 \\
\mathrm{~cm} \text {. }\end{array}$ \\
\hline 4 & $\mathrm{pH}$ & $\begin{array}{l}\text { Measured on spot } \\
\text { collecting water samples } \\
\text { by using portable water } \\
\text { analysis kit. }\end{array}$ \\
\hline 5 & $\begin{array}{l}\text { Dissolved } \\
\text { Oxygen }\end{array}$ & $\begin{array}{l}\text { Measured on the field } \\
\text { itself with the help of } \\
\text { portable water analysis } \\
\text { kit. }\end{array}$ \\
\hline
\end{tabular}




\begin{tabular}{lll}
\hline & & $\begin{array}{l}\text { Measured on the field } \\
\text { itself with the help of } \\
\text { portable water analysis } \\
\text { kit. } \mathrm{CO}_{2}\end{array}$ \\
& Measured in the \\
& Calcium & $\begin{array}{l}\text { laboratory by titrimetric } \\
\text { method }^{[8]} .\end{array}$ \\
\hline
\end{tabular}

Statistical Analysis- The data were analyzed using analysis of variance (ANOVA) while significant means were separated with Duncan's multiple range tests using SPSS 17.0 statistics.

\section{RESULTS}

The water parameters were examined and recorded in three seasons: Summer, Monsoon, and Winter. The table shows seasonal data on the physicochemical parameters of the Sukhana Dam in Aurangabad, Maharashtra, India. The present study deals with the physicochemical properties of the Sukhana Dam at Aurangabad, Maharashtra, India.

Rainfall- It has recorded identical seasonal patterns and is influenced by the southeast monsoon, coinciding with periods of relatively warmer temperatures. The amount of precipitation plays a vital role in regulating the various seasonal biological rhythms. The change in the concentration of the individual chemical components observed hereafter rainwater had entered the dams suggests their effects, affecting the quality of the plankton. Precipitation played an essential role in the annual controls ${ }^{[10,11]}$. The rainfall values were ranged from 0 to $190 \mathrm{~mm}$. The average rainfall values were maximum in Monsoon $114 \pm 46.94 \mathrm{~mm}$ and minimum during summer $4 \pm 39.81 \mathrm{~mm}$ as recorded (Table 1 ). In Sukhana Dam, it was positively co-related with atmospheric temperature (Table 2).

Atmospheric and water temperature- Water temperature is one of the most important properties that decisively determine the trends and trends of quality changes. Temperature is an essential factor influencing the balance of ions and phases and the speed of the biochemical process, which are associated with changes in the concentration and content of organic and mineral substances. Temperature data are also used to calculate the degree of saturation of water with oxygen and other gases. The thermal contamination of the surrounding water significantly affects the aquatic biota and can reduce the water flora and the formation of algal blooms in the water. The atmospheric temperature values were ranged from $19^{\circ} \mathrm{C}$ to $34^{\circ} \mathrm{C}$. The average atmospheric temperature values were maximum in summer $29.75 \pm 4.68 \circ \mathrm{C}$ and minimum during winter $21 \pm 2{ }^{\circ} \mathrm{C}$ as recorded. The water temperature values were reached from 16 to 32 o $C$. The average water temperature values were maximum in summer $27.25 \pm 4.49 \circ \mathrm{C}$ and minimum during winter $19.25 \pm 2.31$ 으 as recorded (Table 2). In the Sukhana Dam, the atmospheric and water temperature was positively correlated to temperature, rainfall, and calcium, and while it was no negatively correlated (Table 3 ).

pH- The normal pH range for surface water systems is between 6.5 and 8.5 and for groundwater systems between 6 and 8.5. The $\mathrm{pH}$ of the water is controlled by the equilibrium that is maintained by the compounds dissolved in the order In natural waters, $\mathrm{pH}$ is primarily a function of the carbonate system, which consists of carbon dioxide $\left(\mathrm{CO}_{2}\right)$, carbonic acid $\left(\mathrm{H}_{2} \mathrm{CO}_{3}\right)$, bicarbonate $\left(\mathrm{HCO}_{3}\right)$ and carbonate ${ }^{[12]}$. The $\mathrm{pH}$ of natural water is generally between 4.0 and 8.5 . Its value is primarily determined by the balance of carbon dioxide, bicarbonates and carbonates. It can be influenced by the change in human substances in the carbonate household due to the bioactivity of plants and in some cases, by hydrolyzable salts. The $\mathrm{pH}$ of water has a significant impact on the toxicity of substances that are usually present in water, especially chemicals that ionize under the influence of $\mathrm{pH}^{[13]}$. The $\mathrm{pH}$ values were ranged from 7.6 to 9.3. The average $\mathrm{pH}$ values were maximum in winter $8.85 \pm 0.38$ and minimum during summer $8.02 \pm 0.26$ as recorded (Table 1 ). In the Sukhana Dam, pH was no positively correlated, and negatively correlated with free carbon dioxide, and dissolved oxygen (Table 2).

Dissolved oxygen (DO)- Dissolved oxygen is a critical parameter that reflects the water quality and is therefore used to classify its variety, especially the water that absorbs the waste. Its consumption during the decomposition of organic substances reduces the concentration to zero and thus reflects the degree of biological contamination of the water. If the waters receive many organic pollutants, the oxygen content drops to zero and the aerobic organisms are destroyed. The study of oxygen content plays a vital role in assessing the habitat conditions of flora and fauna in a body of water. 
Table 2: Seasonal variations in Physico-chemical parameters of sukhana dam July 2008-June 2009

\begin{tabular}{cccccccc}
\hline Parameters & $\begin{array}{c}\text { Rainfall } \\
(\mathrm{MM})\end{array}$ & $\begin{array}{c}\text { Atmospheric } \\
\text { Temp. }\left({ }^{\circ} \mathrm{C}\right)\end{array}$ & $\begin{array}{c}\text { Water } \\
\text { Temp. }\left({ }^{\circ} \mathrm{C}\right)\end{array}$ & $\mathbf{p H}$ & $\begin{array}{c}\mathrm{DO} \\
(\mathrm{mg} / \mathrm{l})\end{array}$ & $\mathrm{CO}_{2}(\mathrm{mg} / \mathrm{l})$ & $\begin{array}{c}\text { Calcium } \\
(\mathrm{mg} / \mathrm{l})\end{array}$ \\
\hline Monsoon & $114 \pm 46.94$ & $25.5 \pm 1.60$ & $23.75 \pm 0.88$ & $8.78 \pm 0.45$ & $9.62 \pm 1.05$ & $7.1 \pm 0.65$ & $29.01 \pm 2.11$ \\
Winter & $17.5 \pm 26.59$ & $21 \pm 2$ & $19.25 \pm 2.31$ & $8.85 \pm 0.38$ & $11.7 \pm 0.40$ & $6.3 \pm 1.86$ & $19.53 \pm 1.94$ \\
Summer & $4 \pm 39.81$ & $29.75 \pm 4.68$ & $27.25 \pm 4.49$ & $8.02 \pm 0.26$ & $10.1 \pm 0.62$ & $10.15 \pm 0.68$ & $23.37 \pm 4.34$ \\
Range & $0-190$ & $19-34$ & $16-32$ & $7.6-9.3$ & $8.4-12.2$ & $4.2-11.1$ & $17.3-31.3$ \\
\hline
\end{tabular}

Table 3: Correlation coefficient of the physicochemical variables of sukhana dam during July 2008 -June 2009

\begin{tabular}{|c|c|c|c|c|c|c|c|}
\hline & $\begin{array}{c}\text { At. } \\
\text { temp }\end{array}$ & $\mathrm{Ca}^{2}$ & $\mathrm{CO}_{2}$ & DO & $\mathrm{pH}$ & $\begin{array}{l}\text { Wt. } \\
\text { temp }\end{array}$ & $\begin{array}{c}\text { Rain } \\
\text { fall }\end{array}$ \\
\hline At. temp & 1 & $0.718^{* *}$ & 0.082 & -0.385 & -0.309 & $0.872 * *$ & $0.622^{*}$ \\
\hline $\mathrm{Ca}^{2}$ & & 1 & 0.035 & -0.540 & -0.179 & $0.581^{*}$ & 0.206 \\
\hline $\mathrm{CO}_{2}$ & & & 1 & 0.648 & $-0.774 * *$ & -0.010 & 0.051 \\
\hline Do & & & & 1 & $-0.711^{*}$ & -0.203 & -0.447 \\
\hline $\mathrm{pH}$ & & & & & 1 & -0.222 & 0.418 \\
\hline Wt. temp & & & & & & 1 & 0.552 \\
\hline Rainfall & & & & & & & 1 \\
\hline
\end{tabular}

** Correlation is significant at the 0.01 level

* Correlation is significant at the 0.05 level

Their presence is essential to maintain higher forms of biological life in the water. The system's oxygen balance largely determines the effects of dirt discharge on a body of water. The dissolved oxygen values were ranged from 8.4 to $12.2 \mathrm{mg} / \mathrm{l}$. The average dissolved oxygen values were maximum in winter $11.7 \pm 0.40 \mathrm{mg} / \mathrm{l}$ and minimum during summer $9.62 \pm 1.05 \mathrm{mg} / \mathrm{l}$ as recorded (Table 1 ). In Sukhana dam, the dissolved oxygen has no positive correlation and is negatively correlated with $\mathrm{pH}$ (Table 2).

Free carbon dioxide $\left(\mathrm{CO}_{2}\right)$ - Carbon dioxide makes up $0.03 \%$ of the atmosphere. It is present in the atmosphere due to biota breathing and industrial combustion, while plants consume it during photosynthesis. Carbonic acid sometimes arises from the dissolution of $\mathrm{CO}_{2}$ in water and also through the decomposition process of organic waste. Surface water contains less than $10 \mathrm{mg} / \mathrm{l}$ carbon dioxide typically. $\mathrm{CO}_{2}$ more water is less alkaline, while $\mathrm{CO}_{2}$ less water is more alkaline ${ }^{[14]}$. The free carbon dioxide values were ranged from 4.2 to $11.1 \mathrm{mg} / \mathrm{l}$. The average free carbon dioxide values were maximum in summer $10.15 \pm 0.68 \mathrm{mg} / \mathrm{l}$ and minimum during winter $6.3 \pm 1.86 \mathrm{mg} / \mathrm{l}$ as recorded (Table 1). Sukhana Dam showed no positive correlation and was negatively correlated with pH (Table 2).

Calcium- The calcium in the water supply leads to passage through or over the limestone, dolomite, gypsum and gypsum reservoir. A low concentration of $\mathrm{CaCO}_{3}$ leads to corrosion of metal pipes when bent or covered. Calcium is an important component of natural water and is released from stones and soil. Concentration up to $100 \mathrm{mg} / \mathrm{l}$. Calcium can scale in pipes and boilers. Happiness has no negative physiological 
effects on human health. A person who drinks water with a certain amount of calcium is less likely to have heart problems or heart disease than a person who contains freshwater without calcium. Calcium values ranged from 17.3 to $31.3 \mathrm{mg} / \mathrm{l}$. The mean calcium values during the monsoon were a maximum of $29.01 \pm 2.11$ $\mathrm{mg} / \mathrm{l}$, and in winter, at least $19.53 \pm 1.94 \mathrm{mg} / \mathrm{l}$, as indicated (Table 1). In the Sukhana dam, calcium was positively correlated with water temperature, and no negative correlations were observed (Table 2 ).

\section{DISCUSSION}

In this study, the maximum summer and pre-monsoon temperatures and the lowest winter temperatures at all sampling points indicate sharp seasonal fluctuations. The increase in the temperature of the surface waters of dams and lakes in each season is due to surface heating and less mixing of the water, which allows a uniform distribution of heat in the water column. The respiration of organisms depends on temperature; The respiratory rate can increase by $10 \%$ or more with a temperature increase of $10^{\circ} \mathrm{C}$. Therefore, high temperature not only reduces the availability of oxygen but also increases the need for oxygen, which can cause a physiological load on the fish, phytoplankton and zooplankton ${ }^{[15,16]}$. Sharma et al. ${ }^{[17]}$ recorded the range of atmospheric temperature $15^{\circ} \mathrm{C}$ to $32 .^{\circ} \mathrm{C}$ in Ban Ganga Stream, Katra; Jammu and Kashmir state. Salve and Hiware ${ }^{[18]}$ recorded the range of atmospheric temperature $25^{\circ} \mathrm{C}$ to $34^{\circ} \mathrm{C}$ in Wanparakalpa Reservoir, Parli V. Dist Beed. Jayabhaye et al. ${ }^{[19]}$ recorded the water temperature ranged $22.5^{\circ} \mathrm{C}$ to $32.5^{\circ} \mathrm{C}$ in minor reservoir. Jawale et al. ${ }^{[20]}$ recorded the water temperature range $23^{\circ} \mathrm{C}$ to $32^{\circ} \mathrm{C}$ in Second Terna Makani Reservoir, Osmanabad, Maharashtra. The $\mathrm{pH}$ of the water determines the solubility (mount that can be dissolved in water) and the bioavailability (the amount that can be used by aquatic life) of chemical components such as nutrients (phosphorus, nitrogen and carbon) and heavy metals (lead, copper, cadmium, etc.). $\mathrm{pH}$ can also determine if aquatic organisms can use it. The degree of solubility of heavy metals determines their toxicity. Metals tend to be more toxic at lower $\mathrm{pH}$ because they are more soluble. Reddy et al. ${ }^{[21]}$ studied Pakhal Lake and was recorded the $\mathrm{pH}$ in the range 7.2 to 8.2. Narayana et al. ${ }^{[22]}$ observed $\mathrm{pH}$ range 7.25 to 7.65 in Anjanapura Reservoir, Karnataka.The amount of oxygen that water can contain depends on the water's temperature, salinity, and pressure. Gas solubility increases with decreasing temperature and decreasing salinity: the partial pressure and the degree of oxygen saturation change with altitude. Gas solubility decreases with decreasing pressure. Therefore, the amount of oxygen absorbed in the water decreases with increasing height due to decreased relative pressure ${ }^{[23]}$. Ingole et al. ${ }^{[24]}$ observed DO range $3.0 \mathrm{mg} / \mathrm{l}$ to $10.3 \mathrm{mg} / \mathrm{l}$ in Majalgaon dam, Dist. Beed (M.S). Karadkhele et al. [25] observed DO range $3 \mathrm{mg} / \mathrm{l}$ to $5.9 \mathrm{mg} / \mathrm{l}$ in Nana Nani park, Latur, Maharashtra. Various workers have also demonstrated such variations for different water bodies. Thus higher levels of free carbon dioxide were primarily due to the decomposition of organic waste. The increase in winter calcium concentration is due to the low water temperature, which increases the solubility of calcium in water et al. ${ }^{[26]}$. The increase during the monsoon could be due to the addition of river basins due to the steady flow of rains ${ }^{[27]}$ and the rapid oxidation of organic matter ${ }^{[28]}$. The decrease was observed in both seasons during the summer season, probably due to calcium absorption by plankton for its growth ${ }^{[29]}$. Barbieri et al. ${ }^{[30]}$ reported that calcium showed a significant positive co-relation of calcium with total hardness, TDS and Magnesium. These studies support our findings.

\section{CONCLUSIONS}

During the present investigation, the range observed parameters were below the permissible limits given by ISI, The water of the present reservoir is useful for irrigation as well as fish culture. The water parameters indicate that the reservoir is rich in nutrients. It can be concluded that Physico-chemical parameters are important to determine the quality of the aquatic environment. In the present study, it performs that the significant positive and negative correlation present in parameters. We can conclude that all the parameters are more or less correlated with each other. Correlation coefficients are used to measure the strength of the association between parameters.

The present work will provide future strategies to improve water quality; there should be continuous monitoring of pollution levels to maintain the favourable conditions of the dam. The continuous biomonitoring of the dam is needed as it affects the flora and fauna of the Sukhana Dam in Aurangabad, Maharashtra.

\section{ACKNOWLEDGMENTS}

The authors are thankful to the Department of Zoology, 
Sambhajirao Kendre Mahavidyalaya, Jalkot Dist. Latur, (M.S.) India for providing laboratory and library facilities.

\section{CONTRIBUTION OF AUTHORS}

Research concept- Dr. S. E. Shinde

Research design- Dr. S. E. Shinde

Supervision- Dr. S. E. Shinde

Materials- Dr. Ashok Sayasrao Munde

Data collection- Dr. Ashok Sayasrao Munde

Data analysis and Interpretation- Dr. Ashok Sayasrao

Munde

Literature search- Dr. P. R. More

Writing article- Dr. Ashok Sayasrao Munde

Critical review-- Dr. P. R. More

Article editing- Dr. S. E. Shinde

Final approval- Dr. S. E. Shinde

\section{REFERENCES}

[1] Shiddamallayya N, Pratima M. Impact of domestic sewage on freshwater body. J. Environ Biol., 2008; 29: 303-08.

[2] Shekhar TR, Kiran BR, Puttaiah ET, Shivaraj Y, Mahadevan KM. Phytoplankton as indicator of water quality with reference to industrial pollution. J Environ Biol., 2008; 29: 233-36.

[3] Chambe A. Assessment of the Factory Impact on Water Quality in Stira River. University of Belgrade., 2014; pp. 1-50.

[4] Kulahrestha H, Sharma S. Impact of mass bathing during Ardhkumbhon water quality status of river Ganga. J Environ Biol., 2006; 27: 437-40.

[5] Mulani SK, Mule MB, Patil SU. Studies on water quality and zooplankton community of the Panchganga River in Kolhapur city J Environ Biol., 2009; 30: 455-59.

[6] Shinde SE. Hydrobiological study of Harsool-Savangi Dam in relation to pollution, Ph.D. thesis, Dr. B. A. M. University, Aurangabad., 2012.

[7] IAAB. Methodology for water analysis, IAAB Editorial Board, Hyderabad (from 1889- 2000) Indian Association of Aquatic Biologists (IAAB), Hyderabad, 1998.

[8] APHA. Standard methods for the examination of water and waste waters, 21st Edn., Washington, DC. U.S.A., 2005.

[9] Trivedi RK, Goel PK. Chemical and biological methods for water pollution studies. Environmental publications Karad, India, 1986.
[10]Shinde SE, Pathan TS, Raut KS, More PR, Sonawane DL. Seasonal variations in Physico-chemical characteristics of Harsool-Savangi Dam, district Aurangabad, India. Ecoscan., 2010; 4(1): 37-44.

[11]Shinde SE, Pathan TS, Raut KS, Sonawane DL. Studies on the Physico-chemical Parameters and Correlation Coefficient of Harsool-savangi Dam, District Aurangabad, India. Middle-East J Sci Res., 2011; 8(3): 544-54.

[12]APHA, AWWA, WEF. Standard methods for the examination of water and waste waters $\left(18^{\text {th }}\right.$ edition). Washington, 1992.

[13] Pondhe GM, Jadhav NS. Physicochemical characteristics and water quality from Puntamba area, Ahmednagar District, Maharashtra State. Paper Published in National Conference of Environmental Issues and Sustainable development, 2000; pp. 7880.

[14]Sarmah BP, Baruah D. Phytoplankton composition in relation to hydrochemical properties of certain floodplain Riparian wetlands of river Subansiri of North Eastern India. Adv Appl Sci Res., 2014, 5(6): 21-30.

[15]Desai PV. Water quality of Dudhsagar river of Dudhsagar (Goa): India (Dept. of Zoo., Goa, University, Taleigo Plateau): Poll Res., 1995; 14 (4): 377-382.

[16]Sharma LL, Sarang N. Physico-chemical limnology and productivity of Jaisamand Lake, Udaipur (Rajasthan). Poll Res., 2000; 23 (1): 87-92.

[17]Sharma KK, Nitasha S, Sarbjeet K. Some limnological investigations in Ban Ganga stream, Katra, Jammu and Kashmir State. J Aqua Biol., 2007; 22 (1): 105-09.

[18]Salve BS, Hiware CJ. Studies on water quality of Wanparakalpa Reservoir, Nagapur, near Parli Vaijnath, dist. Beed, Marathwada region. J Aqua Biol., 2006; 21(2): 113-17.

[19]Jayabhaye UM, Pentewar MS, Hiware CJ. A study on physico-chemical parameters of a minor reservoir, Sawana, Hingoli District, Maharashtra. J Aqua Biol., 2008; 23(2): 56-60.

[20]Jawale CA, Rohikar RV, Mendkudale DV, Babare MG. Seasonal variations in different Physico-Chemical parameters of Second Terna Makani Reservoir in relation to Pisciculture, Osmanabad Dist., Maharastra. J Aqua Biol., 2009; 24(1): 87-90. 
[21]Reddy VK, Laxmi PK, Swamy M, Ravinder RT. Physicochemical parameters of Pakhal Lake of Warangal district andhra Pradesh, India. J Aqua Biol., 2009; 24(1): 77-80.

[22] Narayana J, Puttaiah ET, Basavaraja D, Water quality characteristics of anjanapura reservoir near Shikaripur, District Shimoga, Karnataka J Aqua Biol., 2008; 23(1): 59-63.

[23]Smitha PG, Byrappa K, Ramaswamy SN. Physicochemical characteristics of water samples of Bantwal Taluka, South-estern Karnataka, India. J Environ Boil, 2007; 28, 591-95.

[24]Ingole SB, Pawale RG, Wavde PN. Water quality studies on Majalgaon dam, Beed district, Maharashtra, J Aqua Biol., 2009, 24(1): 71-76.

[25]Karadkhele SV, Lokhande MV, Rathod DS, Shembekar VS, Patil SM. Studies on physico-chemical characteristics of recreational water body in Nana Nani park, Latur, Maharashtra. J Aqua Biol., 2008; 23(1): 55-58.
[26]Borana K, Fayaz FA, Singh M, Romde R. Seasonal variations in physic-chemical parameters of Bishleri stream, Banihal, Jammu and Kashmir. Indian J Biotechnol Pharm Res., 2013; 1(2): 17-23.

[27]Bhandarkar SV, Bhandarkar WR. A Study on seasonal variation of Physico-chemical properties in some freshwater lotic ecosystems in Gadchiroli District, Maharashtra. Int J Life Sci., 2013; 1(3): 207-15.

[28] Pulugandhi C. Analysis of water quality parameters in Vembakottai Water Reservoir, Virudhunagar District, Tamil Nadu-A Report. Res J Recent Sci., 2014; 3: 24247.

[29]Sawhney N. Biodiversity of river Tank in the vicinity of Jammu City. Ph.D. thesis, University of Jammu, Jammu, 2008.

[30]Barberi A, Veronesi M, Simona M, Malusardi S, Straskrabova V. Limnological survey of eight high mountain lakes located in Lago Maggiore watershed (Switzerkabd). J Limnol., 1999; 58(2): 179-92. 